\title{
GRECKA KONCEPCJA PANKALII A WCZESNOCHRZEŚCIJAŃSKIE UJĘCIE PIELKNA ŚWIATA
}

O poozątkón procesu Lormowania się doktryny chrześcijańskiej lezała mýs lyda Filona z Aleksandrii ${ }^{1}$. On to jako pierwszy podjąl próbe dokonania syntezy fllozofil grecklej 1 wiary objawionej bl11. Realizując swoje zamierzenie wykorzystał do alegorycznej interpretacj1 Pisma elementy filozofil pitagorejskiej, platońskiej 1 stołckiej. Założentem kompilacji z tak róznych źródez było przekonanie, iz najlepsza fllozofia grecka 1 religia objawiona sa zgodne w swolch fundamentalnych stwierdzentach. Człowiek jest bowiem głównie dzięki swojej rozumności - stworzony na obraz 1 podobieństwo Boze, totez rozum ludzk1 jest zdolny do odkrycia Prawdy wazdym miejscu 1 wazdym ozasie ${ }^{2}$. Interpretując w ten sposób Biblię, Filon uczynił Ja źródłem donlosłych fllozoficznie 1 moralnie prawd. Ten zinterpretowany fllozoficznie judaizm spotkał sie z zyczliwym zasadniczo przyjęciem ze strony przedstawiciell średniego 1 póznego platonizmu ${ }^{3}$. Mozna by wskazac wiele powodow takiej, a nie innej postany wobec myśli chrześcijańskiej". Jednym z bardziej istotnych punktów spornych była chrześcijańska nauka o Bogu - człowieku. 0 tyle, o lle Filonowa doktryna Logosu była w wielu punktach prekursorska wobec filozof11 Pl tyna, to chrześcijańska nauka o Sło-

1 Por. H. Chadwick, Philo and the Beginnings of Christian Thought, w: Cambridge History of Later Greek and Early Medieval Philosophy, ed. by A. H. Armstrong, Cambrigde University Press, Cambridge $1980^{3}, 137-157$.

2 Por. De spectalibus leglbus IV 61, ed. et trad. A. Mosès, Les oeuvres de Philon d'Alexandrie,t. 25, Paris 1970, 235.

3 Por. P. Merlan, Greek Philosophy Prom Plato to Plotinus, w: Cambridge History ..., s. 99 /autor omawia tu stanowisko Numentusza z Apamei odnośnie do tzw. "mazdrości barbarzyńskiej"/.

4 Temat ten porusza m.1n. S. Kalinkowski we motępie" do przekładu dziefa Orygenesa "Przeciw Celsusowi" AVarszawa 19862\%. Bardziej szczególowe podejmowante tej problematyki wychodzi jednak poza ramy tej praoy. 
w1e Wcielonym była ze mzględow systemowych ostro atakowana.

Nasilajace się ze strony filozofóv pogańskich ataki na doktrynę chrześc1jańską spowodowały, ze pewna część ojców Kościoła zalecała odcięcie się od wpływów pogańskich 1 porzucente fllozofli greckiej na rzecz "filozof11 barbarzyńskiej", którym to mianem określano nauke chrześc1jańska ${ }^{5}$. Większość ojcón nie podzielała tego antyhelleŕskiego stanowiska 1 nie przeciwstawiaka sobie 11lozol11 greckiej 1 religil chrześcijańskiej. Sytuując się niejako na l1n11 Filona z Aleksandril pokazywano, iz waśnie chrzé́c1jaństwo, stanowiac dopelnienie obletnic Starego Testamentu, daje odpowledź na te problemy, z którymi borykała sie mýs starozytna. z taką postawą spotykamy się między 1nnymi w plsmach ów. Justyna Meczennika. Swoje nawrócenie przedstawiak on jako kres intelektualnych poszukiwań, Jako skutek rozczarowań 1 niedosytu, który pozogtawiła w nim filozofia starozytna ${ }^{6}$. Takie stanowisko miało jednakze jeszcze jeden aspekt. Wrkazywało ono na ciagłość, Jaka zachodzi miedzy pewnymi systemami pllozopil grecklej - chodz1 tu głównie o platon1zm - a doktryną chrześc1jańską. Swój optym1zm, co do mozlimości pogodzenia fllozofil platońskiej 1 myśl1 chrześc1Janskiej, motywował Justyn wlaśnie doktryną Boskiego Logosu - Słowa Bozej Mądrośc1 ${ }^{7}$. Chrystus Jest Logosem ukrytym w rzeczach na mocy aktu kreacj1, stąd ten, kto działa 1 mýll1 racjonalnie, uczestniczy w Chrystusie, czy to będzie Sokrates, czy Abraham lub Mojżesz 8 .

5 Por. Tatianus, Oratio adversus Graecos 42, PG 6, 888 B, tłum. M. Michalski, Antologia literatury patrystycznej, I, Warszawa $1975,116$.

6 Por. Justinus, Dialogus cum Tryphone Judaeo 2-7; PG 6, 476-492, POK 4, 99-109.

7 Por. Justinus, Apologia II 13, PG 6, 466-467, POK 4, 93: "Kazdy z nich bowiem z rozsianego Słowa Bożego widział tylko cząstke w sobie kiełkująca, 1 tyle tez tylko mówił prawdy /.../ Pisarze zaś mogl1 widzleć prawdę, aczkolwiek niewyraźn1e, dzięk1 nasieniu Słowa, ktore w nich juz z natury złozone lezało". Justyn posłu-

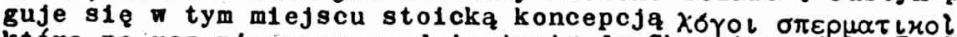
którą po raz pierwszy w odniesientu do Chrystusa jako Boskiego Logosu rozsianego we wszystkich rzeczach spotykamy u Filona; por. Philo Al., Quis rerum divinarum heres sit 119, ed. M. Harl, Les oeuvres de Philon ...., t. 15, Par1s 1966, 224.

8 Just1nus, Apologia I 46, PG 6, 397, POK 4, 53-54: "Chrystus to pierworodny Syn Bozy 1 równocześnie Słowo, wtórem uczestniozy cały rodzaj ludzk1. 0t6z c1, co wiedli zycle ze Słowem zgodne, 
To P1lohellenskie stanowisko podzielała zdecydowana większośc ojców. Postawa ta okazała sie w wielu wypadkach niezwykle twórcza, doprowadzając do powstania róznorodnych systemów 11lozopil chrześc1jańsk1ej. Mýs wczesnochrześc1jańska bow1em, podejmując próbę wyrazenla treści objawienia przy pomocy pojęć, czy nawet całych rozmiazán zaczerpniętych z dorobku starozytnych, nie czerpała z tego dzledzictwa bezkrytycznie. Analizujac podstawy syntezy p1lozofil starozytnej 1 chrześcijaństwa, wielu 0jców Kościoła akcentomało przede wszystkim fakt wzajemnego dopezniania się objawienia Pisma 1 objawienia natury, na co wskazywał juz śv. Pawel w Liśc1e do Rzymian $/ \mathrm{Rz} 1,20-21 /^{9}$.

To zapośredniczenie dziedzictwa greckiego przez myél chrześc1jańska moźna rozpatrywać z róznych punktów widzenia: od strony krytycznej asymilacj1 starozytnych koncepcji metafizycznych, kosmologicznych, antropologicznych, czy wreszcie estetycznych. Proponowane tutaj podejácie do tej problematyki od strony teoril estetycznej 1 to zasadniczo ograniczonej do koncepcji pankal11, wydaje s1e uwypuklać zarówno te elementy, które mý́l chrześc1janska wniosła do dorobku starozytności, jak 1 te punkty, które chrześcijaŕstwo w mnlej lub bardziej twórczy spośbb przekształciło. Poszczególne bowiem zagadnienia nalezace do sfery zainteresowán teoria plękna zakładaja szereg rozwlazań z zakresu teoril bytu, filozoril Boga, antropologil lub kosmologil. Ponadto myśliciele tego okresu posługiwali się zasadniczo pojeciem piękna wziętym pizycznym. Teoria piękna była bowiem $\mathbf{w}$ tym czasie ujmowana $\mathbf{v}$ ścislej zależności od swojej metapizycznej bazy ${ }^{10}$.

W opini starożytnych piękno pierwszorządnie 1 zasadniczo przysługiwało

sa chrześcijanami, choćby uchodzill za ateuszów, jak na przykład wéród Greków Sokrates, Heraklit 1 do nich podobni, a pośrb́d barbarzyńców Abraham, Ananiasz, Azariasz, Misael, Eliasz 1 tylu Innych"

9 Por. Augustinus, De civitate De1 VIII 9-10, CCL 47, 225-227, tłum. W. Kornatowski / $\mathrm{Sw}$. Augustyn, 0 paŕstwie Boży, Warszara $1977 \%$ I 384-385.

10 Por. W: Strózewski, o pojęciach piękna, w: Istniente 1 wartóśc, Krak6\% 1981, 312-335. 
1dea pankal11 znalazła swój pełny wyraz dopiero u sto1kón, to odczucie laktu, ze piękno wszechśwlata jest czymś najbardziej lundamentalnym, znalazło odzwierciedlente juz w samej jego nazwie: swiat został określony jako kosmos/uбojos/, co oznacza porządek, harmonie 1 lad, a pierwotnie termin ten oznaczał ozdobę. Wszechświat nabrał zatem rysów rzeczywistośc1 sakralnej, boskiej. Platon traktował Kosmos jako"największego, najlepszego, najplękniejszego 1 najdoskonalszego z bogów", który moze być ujęty za pomoca zmysłów, okréslajac go jako $\theta \varepsilon \partial s$ a $\sigma \theta \eta \tau o s .11$ Piekno wszechŕwiata wymaga bow1em tego, aby był on 1stotą zywą, obdarzona dusza 1 rozumem, poniewaz "zadne dzieło nierozumne nie będzie nigdy jako całość piękniejsze od dzieła rozumnego jako całośc1, a nie moze mieć rozumu nic, co nie ma duszy. Zwazywszy to sobie, załozył /Demiurg/ rozum w duszy, a dusze w ciele, 1 w ten sposób wszystko zmajstrował, aby wszechświat by $¥$ najpiękniejszym w swej naturzen"12.

Stanowiska myślicieli starozytnych róznicuja się zaleźnie od tego, jaki element przyjmowano za konstytutywny dla piękna. Więszość myślicieli antycznych stała zasadniczo na stanowisku o b 1 ek $t$ y $1 \mathrm{zm} \mathrm{u}^{13}$. 0 pięknie jako takim - takze o pięknie kosmosu decyduja własności obiektywne, przedmiotowe, 1 owo pięno przysługuje rzeczom w sposób be z p o r e d n 1. Przykładem takjego ob1ektywistycznego rozumienla piękna moze byé teoria pitagorejskoplatonska upatrująca 1stoty plękna warmonil proporcji częsci. Relacje między elementami pewnej całości moźna ostatecznie ujać przy pomocy stosunków liczbonych. Matematycznie pojęta proporcja, rozumiana jako zgodność odpowiednich stosunkón liczbowych, stanowiła zasadniczy element $w$ pitagorejskiej teoril piękna. Zdaniem uczniów Pitagorasa liczba była tym eleinentem, który stanowi arche

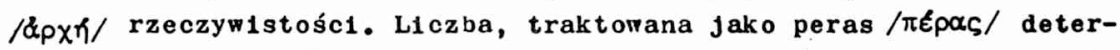

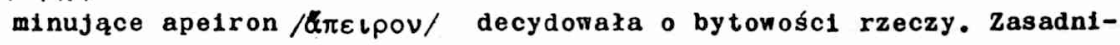

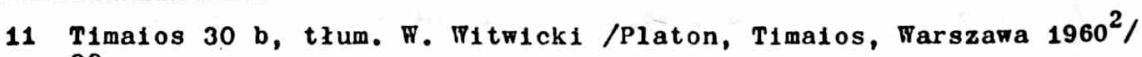
39.

12 Timaios $30 \mathrm{a}-\mathrm{b}$, Hitwicki, 39.

13 Jedyny wyjątek stanowili tu chyba sofíci, którzy " teoril piękna stalı na stanowisku subiektywizmu. 
czym zatem momentem $w$ konstytucji plegna bytu byl element $\mathbf{r}$ m a $1 \mathrm{n} y$, który warunkował bytowość, poznawalność, a co za tya idzie, piekno rzeczy. Ta teoria - poparta autoryteten Platona wskazująca na proporcje, harmonte czę́ci jako na elementy decydujące o pięknie bytu, przez długi okres była w estetyce obowiazująca. Koncepcja ta mlała wielu zwolennikóm mimo to, 1z juz u schyłku starozytności poddana została krytyce przez Plotyna ${ }^{14}$. Plotyriska krytyka nie była radykalnym odrzuceniem koncepcj1 piekna jako harmont1, ale raczej próbą pogodzenia dwóch przeciwstawnych stanowisk obrębie estetyki Platona. Platońska bowiem teoria plękna obok koncepcji piękna jako harmonil - sformułowanej przede wszystkim w Timajosie - operowała jeszcze jedna wizja piekna. W mýs tej koncepcji piękno kazdej rzeczy polega na jej partycypaoj1 | 1de1 piękna ${ }^{15}$. Plotyriska krytyka koncepcj1 piękna jako harmonil wzięta w swojej immanentnej zawartości, okazuje sie cxasen logicznie niekonsekwentna 1 niespójna. Ukazuje ona swą wazność wtedy, gdy ujmie się ja jako próbę wyjścia poza dualizm platońskiej teoril piekna.

Plotyn wprowadził rozróżnienie pomiędzy pięknem formy, tj. plęknem zeunętrznym, a pięknem wewnętrznym. Istotnym czynnikiem - konstytuowaniu owego piękna zewnętrznego jest harmonia, zgodność części. Tak pojęte piękno mosób zasadniczy przysługuje sferze Intelektu. Piękno Nous Noṽc/będące niejako pięknem pustej formy jest "nieporuszone 1 nieporuszajace". Dopiero wtedy, gdy "wyleje się "nań blask, śwlatło, kolor, czy zycie z Dobra, owo piękno stanie się pięknem "zyjacej rormy". Piękno zewnętrzne domaga sie więc dopełnienta ze strony tego, co płynie od Dobra, poniewaz tylko wtedy, pod ozywczym wpływem Dobra, piękno inteligibilne budz1 mi-

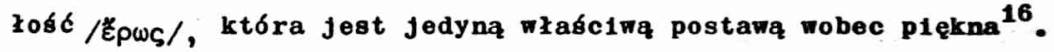

14 Por. J. P. Anton, Plotinus' Refutation of Beauty as Symetry. "The Journal of Ásthetics and Art Criticism" 23/1961/ 233-237.

15 Por. Platon, Symposion 210 a -211 b, tłum. W. Witwicki/Platon, Uczta, Warszawa 1982 /, 113-115:

16 Por. Plotinus, Enneadae VI T, 22, tłum. A. Krokiewicz/Plotjn, Enneady, Warszawa 1959/, II, 598: "I dusza zatem, przyjarszy" do siebie nurt stamtad płynący, doznaje wstrząsu 1 miota sie - upojeniu 1 pełno $w$ niej zędez tęsknoty 1 oto rodzi się milośc. Przedtem zaś nawet wobec umysłu pozostawała niewzruszona, chociaz jest piękny, gdyz z jednej strony nieczynne Jest 
Tak10 ujocie plekna mialo rómiez moje ronsekwonoje dla praktyk1 artystycanej 1 apoczatkowalo - koncepej1 1 : 1 :

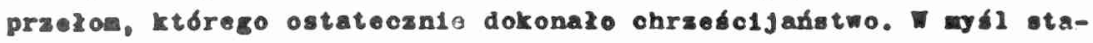
rotytnoj koncopoj1 minezis, neczelnym zadanion sstuk1 bylo nasladownlctwo natury. Artysta nie tworzyl nowych form, locs naśladowal sormy juz 1stniejace. Plotyn okaxujac na lakt, to forma sewnetrzna jest forma pusta 1 dopioro wypezniona prsez ksztalt wewnętrzny staje 1 ezynnik1em decydujacym o plęnie, postulowaz, by artysta odtwarzal wadande ó ksztazt wewnętrzny ${ }^{17}$. Taka koncop-

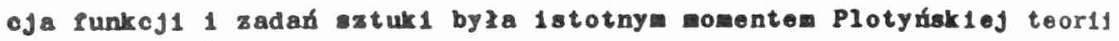

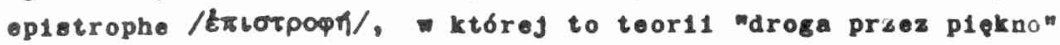
jost jedną z trsech sasadniczych dróg powrotu do Jedn1.

Lýl chrzécijarika przejęa wiele olementó Plotyúkiej teoril piekna, gł́́wnie za pośrednictwem śletego Augustyna. Chrzedoljástwo jednakze, wnosząc odnienna od starozytnej wizje rzeczyw1-

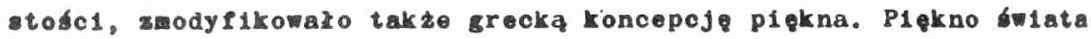
nie polegaio przede wszystki: na takin ozy Innym ukiadzio wasnośc1, Jak tego wymagaz ob1ektyw1za Greków, leoz na tym, zo kosmos by?

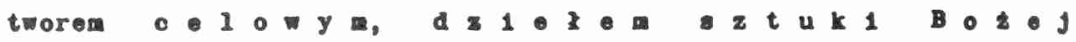
ueleleśnlający w awej atrukturze zamysz Stwórcy. Prokoncepoje taklego rozmiazania mozna odnaleź́ w stolckiej teori1 pankal11, która to koncepcja maza podstaw w teleologicznym ujeciu racezy tośc1. Plękno dotyczyło ni tylko świata jako cazośc1, alo takło kazdej jego czę́c1 apbitworzacej te calośc. Traktując friat jako twór celowy atoley uwazall Nature za Artyatke ${ }^{18}$. będac w pevien

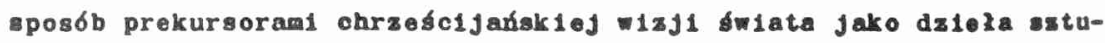
k1 odn1esionego do Boga - Stwórcy. Istnieja jednakze asadnicze

plękno, zan1a rozbzyón1e śriatzem Dobra /.../ p1ękno jest raczej tym, oo promieniuje na wspólmierności/symetri1/, n1t sama -apózuiernościa 1 ze ów wdzlę uroczy to waśnio onom.

17 Por E. de Keyser, La signification de I'Art dans 1 es Enneades de Plotin, Louvain 1955, waszeza 8. 34-39.

18 Seneca, Bpiatulae yo 124, 14, tium. W. Kornatowsk1/Seneka, Listy moralne do Lucyliusza, Farszawa 1961/, 67 \&: Bo pein1 doskonaze jest to wylifeznie, co jest doskonaz odpowiednio do powsachnej natury, a natura powsechna jest rozumnaw. 


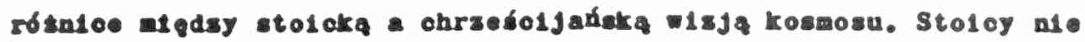
epormukowal koncepej1 tranecendentnego Boga - Stwórcy wyprowada

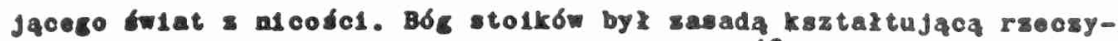
wietof́c od wewastre jako Prawo, Rosua, Natura ${ }^{19}$.

Nastepny krok roswoju obrzefoljaxistioj koncepcj1 pankal11

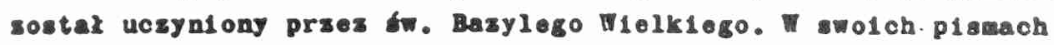
Basyl1 nlejednokrotn10 wakazuje na celowośó struktury f́wata, która decyduje o pleknle kosmosu 1 wyraka zanys Artysty bşdącego jogo

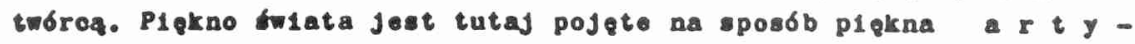
- to n o. o. toor11 plekna odrzuciz Bazyl1 ob1oktyw1 a

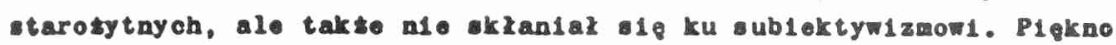

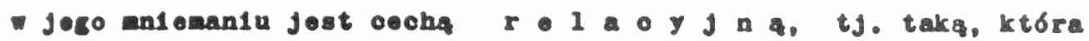

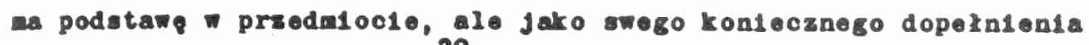
wymaga ujeola podmiotowego ${ }^{20}$. Iwoste te podejale j́w. Augustyn atawajac pytanie: $\mid / . . . /$ ozy dlatego cof jest piekno, to sie podoba,

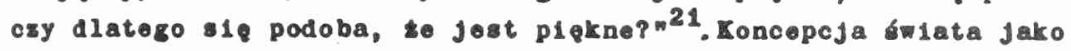

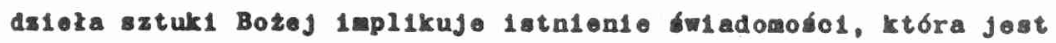
sdolna ujab to dalezo w jego artyzmie. Plekno kosmosu traol teras soj absolutny charakter, na czoło wybljaja lo zal jogo runkoje:

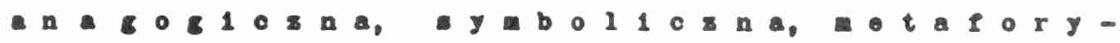
- a a. Bón1 mýr1c1ele odmienny - salezny od kontekstu systemowego posb, charakterysowal 1 te Punkoje.

P1 gkno - wodkug fw. Augustyna - przejaw1a 1 . konkrec10 jako orreślona postad /spec1es, forma/22, bequea konsekwencja formy rmecsy, tj. zasady, kt6ra dooydujo o 1stnloniu bytu 1 jogo posmaval-

19 Por. Seneca, Bplstulae VII 65, 12, Kornatowak1 226: My Jedaakte sukamy teraz najplerwszej 1 ogónej przyczyny. Ta powinna by ó calkien prosta. Chcemy wiedzlec, co jest ta prsyczyną? Jest nda, a 1 rozumiec, twórczy rozun, to zaozy Bóg

20 Por. Basil1us, Hoall1a in Bexaeseron II 7, SCh 26, 170-172.

21 Augustinus, Do pera rel1glone 32,59, CCL 32,226 , thun.

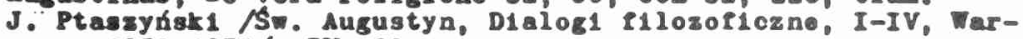
cava 1953-1954/, IV 122.

22 U f́. Augustyna takie terminy, jak apecies czy forma, zwaszosa jeśli maja dodatkow okrélienla: Porma formosa, sec1es - peciosa, oznaczaja nio tylko form rzeczy, lo 1 plekno konkrotu. Por. J. A. Masseo. The Augustinian Conception of Beauty and the Dante' Conv1v10, The Journal of Aesthetsos and Art Critioisa 15/1957/436-437. 
nośc1 ${ }^{23}$. Postać ta jest na zewnątrz konstytuowana przez odpowiedn1 układ elementów tworzących Indywiduum oraz poprzez wewnętrzne zrelacjonowante do jednośc1 ${ }^{24}$. Wajemna zgodność elementów oraz $1 \mathrm{ch}$ dopasowanle do całości jest miarą piękna, którą ostatecznie moźna wyrazıć liczbą. Z tych względów św. Augustyn definiował piękno jako "aequalitas numerosa" - odpowiedniość, równość liczbową 25. Liczba ta ma swoja podstawe w numerus sempiternus - absolutnej liczbie Bożej Mądrości ${ }^{26}$, zaś od strony podmiotowej piękno pojęte jako aequalitas numerosa implikuje 1stnienle podmiotu "liczacegon, zdolnego do ujęcia liczbowej struktury świata. Uzasadnieniem tej matematycznej struktury swiata jest liczbowa struktura duszy 27 , która jako transcendująca czas 1 przestrzeń, zostaje podniesiona do oglądu miecznych 11czb", utożamiaj zcych się z Bożymi Ideami. Kazda rzecz materialna zostaje zatem ustanowiona jako vestigium slad Boga. Będąc zaś Bozym znakiem, rzeczy mają za zadante nakierowywanie mýlli człowieka ku jego wasnemu wnętrzu, aby tam odnalazł obraz Boga/imago Dei/. Według Augustyna bowiem wszelka droga ku Bogu wiedzie poprzez ludzka duszę. Podziw dla Bozych dziel ma naprowadzać myśl ku samej Bozej sztuce /ars/ 1 jej prawom /leges artium/, a ostatecznie ku samemu Stwórcy /Artifex/. Plękno sposób właściny przysługuje tylko Boskiemu Artyście, rzeczom zaś na mocy $p$ a $r$ y Pseudo-Dionizy chcac oddać pełnlę 1 wzniosłość Bozego piękna

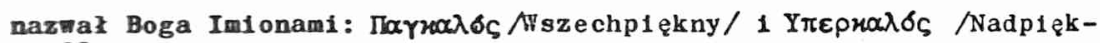
ny $/^{28}$. Boze p1ękno, będące identyczne z dobrem, skupia w sobie

23 Por. Augustinus, De vera religione 20,401 18, 35, CCL 32, 211 i 208, Ptaszyński 106 1 103; De immortalitate animae 8, 13, PL 32, 1027-1028, tzum. M. Tomaszewski /Dialogi filozoficzne/, II 92 .

24 Por. Augustinus, De vera religione 41, 77, CCL 32, 237, Ptaszyńsk1 135.

25 Augustinus, De musica VI 13, 38, PL 32, 1184, tium. D. Turkow8ka /Dialogi Pllozopiczne/, IV 56: "Otóż te rzeczy piękne podobaja sie nam dzięki zawartej w nich liczbie, której celem, jak Już wykazaliśmy, jest równość".

26 Por. Augustinus, De libero arbitr1o II 11, 32, CCL 29, 259, tłum. A. Trombala/Dialog1 fllozoficzne/, III, 143-144.

27 Por. Augustinus, De musica VI 10, 25, PL 32, 1177, Turkowska 45-46.

28 Por. Pseudo-Dionysius Areopagita, De divinis nominibus IV 7 , 
cały krąg przyczynowoścı przypisywany dobru ${ }^{29}$. Jako przyczyna sprawcza konstytuuje ono rzeczy, będące symbolam $/ \varepsilon$ trova/absolutnego piękna stanowiącego $1 \mathrm{ch}$ źródło ${ }^{30}$. Natomiast jako przyczyna formalna, wzorcza ${ }^{31}$ a nawet materialna ${ }^{32}$, nadaje rzeczom byt 1 trwanie, a Jako przyczyna celowa, Boze piękno pociaga wszystkie rzeczy ku sobie dla $1 \mathrm{ch}$ przebóstwienia ${ }^{33}$.

Myśliciele chrześcijańscy kładąc nacisk na lakt, ze wszystko, cokolwiek istnieje w świecie jest dziełem Boga, 1 nic - nawet materia - nie pozostaje poza zasięgiem Boskiego aktu stwórczego, w sposób 1stotny zmodyfikowali starozytne koncepcje $t$ w $6 \mathbf{r}-$ c z o ś c $1^{34}$. Właścimie dopiero chrześcijaństwo mprowadziło poJęcie twórczośc1 jako kreacj1, powoływania do bytu tego, co przedtem nie 1stniało w żadnej formle. Starożytność grecka na oznacze-

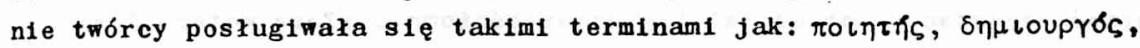

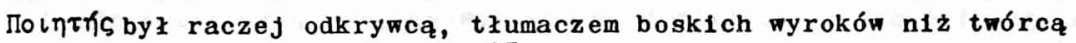
w pełnym tego słowa znaczeniu ${ }^{35}$, chociaż jego działalność była bardziej swobodna niz działalność demiurga, bo nie skrępowana regułami wytwarzania.

PG 3, 701 D, tłum. E. Bułhak /Dzieła świętego Dionizyusza Areopagity, Kraków 1932/, 37.

29 Tamze, IV 10, PG 3, T05 D, Bułhak 40.

30 Tamże, V 4, PG 3, 817 C, Bułhak 63: "/.../ dobro jest prawdziwym bytem $\% \ldots /$, ono to daje byt wszystkim rzeczom".

31 Rozwlazantem problemu przyczynowości wzorczej 1 formalnej w systemie Pseudo-Dionizego, stanowi jego specyficzna koncepcja

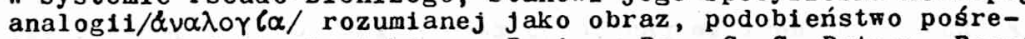
dniczące między człowiekıem a Bogiem. Por. C. C. Putnam, Beauty in the Pseudo-Denys, Washington 1960, 41-46/Autorka idzie tutaj zasadniczo za ustalentami pracy V. Lossky'ego: La notion des "analogies" chez Denys le Pseudo-Areopagite, "Archives de l'histoire doctrinale et littéraire du Noyen Age" 5/1930/ 279-309

32 De divinis nominibus IX 3, PG 3, 912 A, Bułhak 85: "Przypisuja Bogu małość, drobność czyii subtelność, bo nie ma nim ani masy, ani roziegłości i przenika wszystko bez przeszkody. Nadto małość jest elementem 1 zasada wszystkich rzeczy 1 nie znajdziesz absolutnie nic, co by nie by ło małen pod pewnym względem".

33 Tamze, IV 14, PG 3, $712 \mathrm{C}$, Bułhak 44: "/.../ nazywa sie m1łośc1a

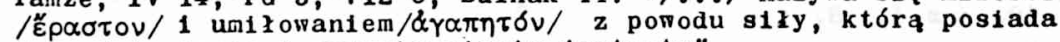
do podniesienia 1 przyciagnięcia jestestw".

34 Por. T. Tatarkiewicz, Dz1eje sześciu pojęc, Warszawa $1976^{2}, 296 \mathrm{n}$

35 Por. Plato, Symposion 202 E - 203 A, Witwick1 101. 
którego praca byla sdetorminomana przez dostęne nu tworzywo 1 k1erujace jego gamsisen 1dee. Ponadto termin b́nj loppyóç oznaczaz często nloosobowa przyczyae bytu 1 tya aspekele byl synonimeir terminu alc la. 36

W $12 j 1$ chrzeŕc1jarik1 J natom1ast Bóg Stwórca/Creator/ jest w smojej dziazalności cazkow1010 wolny: ne jest bowlem ograniczony and przez tworzywo, and przez zewnętrzny wobeo nlego wzór. Wszystko, cokolwiek $18 \mathrm{tnleje}$ stanow1 kres Bosklego Aktu Stwórczego, totez - doktrynie chrzécijarikiej nie ma miejsca na preegzyatencje mater11. Bóg stwarza śv1at ex n1h1lo, a jako wzór szuzy mu układ Botych Ide1 utozsamiajacych io z jego Umysiem. Taka koncepcja rzeczywistośc1 koryguje poglad starozytnych w k1lku asadniczych punktach. Podkreślajac, te mzystko, cokolwek latnleje jest dzierem Boga, chrześc1janstwo spośb 1stotny dowartościowuje sere materialna. W tradycj1 platorikiej materia byza traktowana jako principium niedoskonałośc1 1 zla. Plotyn 1 jego następcy usilowall odseparować od Éwlata Jednie - Dobro przy pomocy szeregu pośredniczacych hipostaz, aby ten sposób odsuną́ podejrzenie, ze absolutne Dobro mogłoby byé przyczyna nledoskonałośc1, zła 1 brzydoty. Chrześcijaristwo zas utrzymujqo, te wsygtko, cokolw1ek $18 \mathrm{tn} 1$ eje - nawet materia jest dzlezen Bogkiej Dobroci, sformulowalo koncepcje zla 1 brzydoty jako br ak u. Kazdy byt o tyle, o 11 e 1stnleje jest dobry 1 plekny, a zzo 1 brzydota to brak odpowiedniego dobra 1 pleqna, a nie jakaś pozytywna bytowośc ${ }^{37}$.

Koncepcja creatio ex nihilo pociaga za soba odrzucente tezy - พ1ecznośc1 kosmosu, gdyz wszyst从o w świecie zostało stworzone wraz $z$ czasea. Stanowi to radykalne zerwan1e $z$ absolutyzacja 1 sakralizacja kosmosu. która miała miejsce u mý́llcieli starozytnych. Platon uwazal, 1t kosmos mial poczłtek w czasie, gdyz czas zostak stworzony wraz ze ́́wiatem, aby upodabniá go do wieczności. Zerwawszy z odwiecznościa śliata, Platon glosik jednak jego wiecznotrwa-

36 Por. W. Strózewsk1. Problem panteizmu De divinis nominibus Pseudo-Dionizego Areopagity, "aocznik1 Pilozoflcznew 5/1955$1957 / \mathrm{z} .3,48$.

37 Por. De divinis nominibus IV 27, PG $3,728 \mathrm{D}$, Buthak 56. 


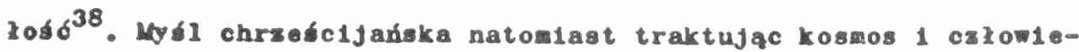
ka jako to, co jest creatuo, zrównuje stworzenia w oczach stwórcy. Czkow1ek zostaje wywyzsony nawet ponad reszte stworzeń jako ta Jedyna 1stota, która nosi woble obraz 1 podobieństwo Boze. Konsekwencja tego jest zanegowanle ostrego przedzlaku, który mýs atarobytna wprowadzila miedzy sfera inteligibilna a zarysiow. Nie ma Juz ontyoznej przepáci medzy tym, co inteligibilne a tym, co zaysıowe, lecz między Bogiem transcendentnya stwórca a tym wsystkim, co jest jego dzielem. Niezwykle doniosła pozycja człowieka mieo1. polega miegdzy 1nnymi na tym, ze jest on lącznikiem miedzy tyml serami, które mýs antyczna ostro sobie przeciwstawiaza ${ }^{39}$.

Jan Szkot Eriugena dat swolch p1smach wizje ozlowieka jako tej 1stoty, dla ktorej 1 wióroj zostaly atworzone wszystkie byty stojace nizej wherarch11. Wynfku grzechu Adama cake stworzenie upadıo wielość áviata materialnego, stạd cziowiek musi być tym, który doprowadzi z powrotem cale stworzenie do stwórcy. Prooes powrotu czlowieka - a z nim wazystkiego, co zostako stworzone - do Boga, rozpoczyna sia wraz odozytywaniem boskich teoran11 lub metafor. Do 1 stoty metafory nalezy to, te odsianiajac pewna tréć skierowuje jednoczénle myśl ku ukrytej, 1nteliglbilnej podstawie tych treści. Eriugena okréslil to jako dialektyke tego, co jawne /manlfestum/ 1 tego, co ukryte /occultum/. Człowlek odczytujaco owa Jawną tré́ć przechodzi ku głębszy poziomom rozumienia, które problematyzuja wynlk1 plerwszego etapu poprzez wskazanie na $1 \mathrm{ch}$ nieadekwatność obliczu źródła 1 podstawy wszelk1ej metafory ${ }^{40}$. Wa-

38 Platorski opls stworzenia ślata usiłowano niejednokrotnie uzgadniać oplsem K Ksiegi Rodzaju. ZwIagzcza w XII wieku w szko10 w Chartres potyka sle liczne komentarze do T1majosa; por. Wilhelm z Conches, Glossae super Platonem, ed. E. Jeauneau, /Par18 1965/63: Fruit autem ignoratus/to jest T1malos/ usque ad tempus 0s11 episcopl qui cum sciret in eo multa ut1 1 a nec lide1 contraria continer1, rogavit Calcidium /.../ ut de greco In latinua 111 um transforret".

39 Por. 1. Kurdz1azek, Stredniow1eczne doktryny o człowleku Jako obrazle ǵviata, "Roczniki Pllozoficzne" XIX, 19/1971/, z。1, 3-39.

40 Jest to nlezwykle interesujaca 1 jedna z fundamentalnych da Jana Szkota Erlugeny mýr l, która motna by okré́líf jako problem wajemnych relacjl loologil pozytywnej 1 teologil negatywnej. Te nurty 11 lozolicane, które rókny sposób nawlązywąy do neoplatonizm, preferowaly owa mroge prsez negacjem. 
runkiem możliwości metafory jest to, ze Bóg istotnie konstytuuje śmiat jako teofanię, a siebie jako ukryte jej źródło ${ }^{41}$. Człowiek ujmując Boską bazę metafory skierowuje swą myśl na powrót ku źródłu wszelkiej rzeczywistośc1. Proces powrotu nie stanowi prostego osiagnięcia stanu utraconego. Istota ludzka powraca do swojego źródła wzbogacona o świadomość kosmicznych "dziejów". W kontekście specyficznych załozeń systemu Eriugeny, anagogiczna, metaforyczna funkcja piękna świata materialnego uzyskuje nowy 1 bardzo specyficzny rys. Ujęcie świata jako metafory jest nie tylko droga do przebóstîienia świata 1 człowieka, ale także droga samopoznania Absolutu. Bóg będąc czymś absolutnie prostym 1 jednym, poznaje siebie tylko wtedy, gdy ukonstytuuje sie $\mathbf{w}$ śwecie jako przedmiot. Dzięki konwersji człowieka moze on powrócić do siebie jako świadomość wzbdgacona. Kosmos nie jest juz wyłącznie ksiegz, w której człowiek odczytuje ślady Boga, ale także księga, z której Bog odczytuje własną autobiografie.

\section{Agnieszka Kijewska - Lublin}

\section{THE GREEK THEORY OF PANKALIA AND EARLY CHRISTIAN CONCEPTION OF BEAUTY \\ /Summary/}

This paper refers to the fundamental problem of aesthetics in the period of later Greek and early Medieval thought. The basic problem discussed here is the one of modification of Ancient theory of pankalia under the influence of Christian thought. Greek opinions were that the world taken as a whole was beautiful and the beauty was primarily due to the world. Beauty was established by objective qualities of things, particularly these elements which were the reasons of being and inteligibility, that is, the formal factors. Christian aesthetics, formulating the theory of world as the Work of God's Art rejected ancient objectivism and accepted the opinion

41 Por. Johannis Scotti Eriugenae Periphyseon/De divisione naturae/, III, ed. by I. P. Sheldon - Williams, Dublin 1981, 160162: "Proinde non duo a se ipsis distantia debemus intelifgere deum et creaturam, sed unum et id 1psum. Nam et creatura in deo est subsistens et deus in creatura mirabili et ineffabili modo creatur se ipsum manifestans, invisibilis visibilem se faciens et incomprehensibilis comprehensibilem et occultus apertum et incognitus congnitum et forma ac specie carens formosum ac speciosum et superessentialis essentialem et superessentialis naturalem et simplex compositum et accidentibus. liber accidentibus subiectum/et accidens/ et infinitus finitum et incircumscri tus circumscriptum et supertemporalis temporalem et omnia creans in omnibus creatum et factum omnium factus in omnibus et aeternus oepit esse et immobilis movetur in omnia et fit in omnibus omnia. 
which says: the indispensible condition of beauty is a subjective Pactor apart from objective elements. Beauty does not belong to things in direct way but belongs because of participation in absolute Creator's Beauty. That is why beauty has got the anagogic, symbolic Punction leading to the knowledge of God's Wisdom. Besides, the Christian aesthetics introduces the conception of creativity as a creation, that means, calling into being everything what was existent in no form previously. In the aftermath of it involves the modification of conception mimezis. The goal of mimezis is not repetition of existing forms, but arrival at the patterns of things, that is at the ideas in'the Creator's Mind. 